\title{
DETECTION OF POTENTIALLY TOXIGENIC MICROCYSTIS STRAINS FROM DAU TIENG RESERVOIR
}

\author{
Pham Thanh Luu ${ }^{1,2, ~}$, Ngo Xuan Quang ${ }^{1,2}$ \\ ${ }^{1}$ Institute of Tropical Biology, Vietnam Academy of Science and Technology \\ ${ }^{2}$ Graduate University of Science and Technology, Vietnam Academy of Science and Technology \\ ${ }^{\square}$ To whom correspondence should be addressed. E-mail: thanhluupham@gmail.com
}

Received: 03.4.2017

Accepted: 28.12.2017

\section{SUMMARY}

\begin{abstract}
Microcystis is a bloom-forming, common cyanobacterium in Dau Tieng reservoir used for public water supply. To assess the presence of potentially microcystin-producing Microcystis, molecular techniques were conducted and acute toxicity bioassays were performed with the microcrustacean Daphnia magna exposed to cyanobacterial crude extracts. Potentially toxigenic of isolated strains was characterized by amplifying $m c y D$ genes and identification of Microcystis was confirmed by 16S rRNA amplification. Microcystins (MCs) concentration in bloom samples and cultured strains were quantified by High Performance Liquid Chromatography (HPLC). Results showed that there were 9/15 strains showed positive with the $m c y D$ marker indicating that they are toxic strains. Three MCs variants including MC-RR, -LR and -YR were found in all extracts of toxic strains with the highest concentration of $1,218 \mu \mathrm{g} / \mathrm{g}$ dry weight (DW). The acute toxicity bioassays revealed that both toxic and non-toxic crude extracts elicited significant lethal effects on the tested animal with LC50 values ranged from 189-411 mg DW/L. The toxic effects of isolated strains were independent from the MCs concentration in some strains suggesting the presence of other metabolites contributed to the biological effects. In conclusion, microcystin-producing Microcystis from the Dau Tieng reservoir warn about possible toxic effects for aquatic biota and human health.
\end{abstract}

Keywords: Microcystin producing, Microcystis, mcy gene, PCR detection, Dau Tieng reservoir

\section{INTRODUCTION}

Blooms of cyanobacteria (blue-green algae) have been occurred in eutrophication freshwater bodies all over the world, including Vietnam. Bloom forming of cyanobacteria has created a significant water quality problem, as some species are capable of producing cyanotoxins. Among cyanotoxins, microcystins (MCs) are the most prominent cyanobacterial hepatotoxins in freshwater (Chorus, Bartram, 1999). The MCs are cyclic heptapeptide hepatotoxins synthesized non-ribosomally by a multifunctional enzyme complex that includes peptide synthetase (NRPS) and polyketide synthase (PKS) modules, both of which are encoded by the microcystin synthetase gene $(m c y)$ cluster, which contains $55 \mathrm{~kb}$ of DNA and has been characterized in many cyanobacterial genera (Nishizawa et al., 1999; Tillett et al., 2000; Rouhiainen et al., 2004). More than $80 \mathrm{MCs}$ structural variants have so far been reported worldwide (Dittmann, Wiegand, 2006).
MCs are powerful inhibitors of the proteins phosphatases (PP) 1 and (PP) 2A, causing strong hepatic hemorrhage.

Many species belonging to the genera such as Dolichospermum, Microcystis, Oscillatoria, Nostoc, Aphanizomenon and Pseudanabaena can produced MCs (Chorus, Bartram, 1999; Ballot et al., 2004). Morphological methods could be used to identify difference genera. However, these methods could not be used to recognize toxic and non-toxic cyanobacterial species because many strains of cyanobacteria appear to be identical under the microscope. Blooms of cyanobacteria usually consist of toxic and nontoxic strains (Janse et al., 2004). Several techniques to identify toxigenic strains have been developed for cyanobacteria. Among them, the presence or absence of the $m c y$ gene cluster has been widely used as a means for distinguishing the two genotypes and has been recently used to reveal the presence of MC-producing cyanobacteria in both 
environmental samples and axenic cultures (Nishizawa et al., 2000; Rantala et al., 2006; Pedro et al., 2011).

Cladocerans are the most used group in ecotoxicological studies, especially the daphnia species Daphnia magna (Sarma, Nandini, 2006). However, previous studies often used purified toxins for toxicity test. The toxicity assessment of purified cyanotoxins on Daphnia may not reflect at all events occurring in the environments, as it has been reported that the toxicity of Microcystis is susceptible to be modified when they are associated to other molecules (Burýšková et al., 2006). Hence, it is better to use crude extracts for evaluating the toxic effects as they have occurred in natural environments after blooms decay.

Long term blooms of cyanobacteria are common in Dau Tieng reservoir (Pham et al., 2015). This problem poses a risk not only for the aquatic organisms but also for human and biota of the neighbouring areas. Monitoring quality of water destined to public supply includes identification of potentially toxic cyanobacteria and their toxicity. This information is extremely useful to prevent against the possible risk of intoxication when human populations or natural biota are exposed to water from sites where Microcystis blooms are occurring. Considering the increasingly frequent toxic blooms in tropical aquatic ecosystems and the scarcity of reports on potentially toxin-producing cyanobacteria populations and their toxicity in Vietnamese waters, this study aimed to detect Microcystis strains with the genetic potential to produce MCs independent of their taxonomic category and their toxicity at relevant environmental conditions.

\section{MATERIALS AND METHODS}

\section{Sample collection}

Bloom samples from the Dau Tieng reservoir were collected by skimming across the water surface using bolting silk plankton net of 25 micron mesh size. These samples were kept cool $\left(25^{\circ} \mathrm{C}\right)$ and brought to the laboratory. Samplings were performed only during July of 2016, when the selected sites contained predominantly blooms of Microcystis sp. The samples were concentrated by placing the material in glass cylinders and the buoyant cyanobacterial scum collected from the surface. The natural biomass samples were dried at $45^{\circ} \mathrm{C}$ overnight and kept at $-20^{\circ} \mathrm{C}$ until further processes.

\section{Isolation and cultivation of cyanobacteria}

Cyanobacteria were isolated by micropipetting and washing. A single cyanobacterial colony of Microcystis was isolated by micropipetting, washed, and transferred into cyanobacterial growth medium (Belcher, Swale, 1988). Cyanobacteria were grown in Z8 medium (Kotai, 1972). All cultures were grown on a $12 \mathrm{~h}: 12 \mathrm{~h}$ light:dark cycle at temperature of $28^{\circ} \mathrm{C}$ under light conditions provided by $40-\mathrm{W}$ fluorescent lamps, which provided an approximate luminic intensity of $20 \mu \mathrm{mol}$ photons $/ \mathrm{m}^{2} / \mathrm{s}$. Biomasses of cyanobacterial cultures were harvested onto GF/C fiberglass filters (Whatman, Kent, England), dry at $45^{\circ} \mathrm{C}$ overnight and kept at $-20^{\circ} \mathrm{C}$ until further processes.

\section{Identification of cyanobacteria}

Cyanobacteria were observed at $400 \times$ magnification under a microscope Olympus CK40F200 equipped with a digital camera (Olympus, Tokyo, Japan). Taxonomic classification was based on the system of Komárek and Anagnostidis (1989, 1999, 2005). Descriptions of cyanobacteria were based on observations of both preserved and cultured samples.

\section{Preparation of the crude extract}

Cyanobacterial crude extracts (CCE) were prepared according to Pietsch et al., (2001) with some modifications. Briefly, $2 \mathrm{~g}$ dry weight (DW) of the bloom material or isolated culture was dissolved into distilled water, frozen at $-70^{\circ} \mathrm{C}$ then thawed at room temperature. After the materials thawed completely, they were sonicated for three min. This freeze-thaw-sonicate cycle was repeated five times. The samples were then centrifuged at $2000 \times \mathrm{g}$ for $10 \mathrm{~min}$ to remove cell debris. The supernatant was collected and kept at $-20^{\circ} \mathrm{C}$ until use for the toxicity experiments.

Sub samples of the CCE supernatant were used for MC analysis as previously reported by Pham et al., (2015). Briefly, $100 \mu \mathrm{L}$ of the supernatants was centrifuged at $4000 \times \mathrm{g}$ for $15 \mathrm{~min}$. The supernatant was collected, dried completely, and re-dissolved in $500 \mu \mathrm{L}$ of $100 \% \mathrm{MeOH}$. The samples were analyzed by HPLC system with UV-visible photodiode array (PDA) detector (Shimadzu 10A series, Kyoto, Japan). Commercial MCs from Wako Company (Osaka, Japan) were used as standards.

\section{Acute toxicity bioassays}


D. magna Straus purchased from the MicroBioTests Inc, Belgium was used for the test. The animal were raised in ISO medium and fed by a mixture of viable green algae Chlorella sp. and Scenedesmus sp., which were cultivated in COMBO medium (Kilham et al., 1998) with continuous aeration. Both Daphnia and algae were maintained in the laboratory conditions at $25 \pm 1{ }^{\circ} \mathrm{C}$, with a 14h:10h light:dark cycle.

Acute toxicity bioassays were performed, according to the Protocol 202 of the Organization for the Economical Cooperation and Development (OECD, 2004), compatible with the procedure proposed by the U.S. EPA (2002). Briefly, D. magna neonates $(<24 \mathrm{~h}$-old $)$ were maintained in ISO medium containing CCE. For each crude extracts, at least five different concentrations with a dilution factor of 0.5 were tested in triplicate by exposing 10 neonates per replicate. Test containers were placed in an environmental beaker at a controlled temperature of $25^{\circ} \mathrm{C}$ and a $14: 10 \mathrm{~h}$ photoperiod during $48 \mathrm{~h}$. The assessed response was immobility or death of cladocerans. The criterion for test acceptance was a survival higher or equal to $90 \%$ in the control group. Finally, mortality data recorded at the end of the toxicity tests $(48 \mathrm{~h})$ were used to determine the Median Lethal Concentration (LC50) through Probit analyses by using the SPSS software according to the method of Stephan (1977).

\section{DNA extraction}

Total genomic DNA was extracted from cyanobacterial retained on filters following the methods described previously in Hisbergues et al., (2003) with minor modifications. Briefly, the filters contained cyanobacterial cells were suspended in TE buffer (50 mM Tris/HCl, $40 \mathrm{mM}$ EDTA, $\mathrm{pH}$ 8.0). An aliquot of $30 \mu \mathrm{L}$ of $10 \%$ SDS (sodium dodecyl sulfate) and proteinase $\mathrm{K}$ (final concentration: 100 $\mu \mathrm{g} / \mathrm{mL}$ in $0.5 \%$ SDS) was then added and incubated for $60 \mathrm{~min}$ at $37^{\circ} \mathrm{C}$. Then $5 \mathrm{M} \mathrm{NaCl}(100 \mu \mathrm{L})$ and $\mathrm{CTAB} / \mathrm{NaCl}$ solution $(10 \% \mathrm{CTAB}$ in $0.7 \mathrm{M} \mathrm{NaCl})$ $(80 \mu \mathrm{L})$ were added, and the samples were incubated for $10 \mathrm{~min}$ at $65^{\circ} \mathrm{C}$. DNA was then extracted twice with phenol:chloroform:isoamyl alcohol (25:24:1 $\mathrm{v} / \mathrm{v})$. After centrifugation for $5 \mathrm{~min}$ at $6000 \times g$ at $4^{\circ} \mathrm{C}$, the supernatant was collected and transferred to a fresh tube. The DNA was then rinsed with $1 \mathrm{~mL}$ of $70 \%$ ethanol and dried under vacuum. The final DNA sample was rehydrated in $20 \mu \mathrm{L}$ of $1 \times \mathrm{TE}$ buffer (10 mM Tris and $1 \mathrm{mM}$ EDTA $\mathrm{pH}$ 8.0).

\section{PCR amplification}

The polyketide synthase fragment $(m c y D, 297$ bp) was amplified using primer pair mcyDF2/mcyD-R2 (Kaebernick et al., 2000). To detect the presence of cyanobacterial DNA, the CYA primer pair (Urbach et al., 1992) was used to amplify a $1200 \mathrm{bp}$ fragment of the 16S rRNA gene common to all cyanobacteria. For each sample, two separate PCRs were conducted. All PCR reactions were prepared in a volume of $20 \mu \mathrm{L}$ containing $2 \mu \mathrm{L}$ of 10 $\times$ Ex-Taq Buffer, $200 \mu \mathrm{M}$ of each dNTP, $0.5 \mu \mathrm{L}$ of each primer $(10 \mu \mathrm{M}), 0.5 \mathrm{U}$ of Ex-Taq polymerase (Takara Bio Inc., Shiga, Japan), and 20-25 ng of template DNA. Amplification was performed in a Thermal Cycler (Applied Biosystems, Foster City, California, USA) follow the condition: initial denaturation at $95^{\circ} \mathrm{C}$ for $10 \mathrm{~min}, 35$ cycles $\left(94^{\circ} \mathrm{C} / 1\right.$ $\min , 54^{\circ} \mathrm{C} / 1 \mathrm{~min}, 72^{\circ} \mathrm{C} / 1.5 \mathrm{~min}$ ) and a final extension step at $72^{\circ} \mathrm{C}$ for $10 \mathrm{~min}$. PCR products were examined on $1.5 \%(\mathrm{w} / \mathrm{v})$ agarose gels stained with ethidium bromide and photographed under UV transillumination.

\section{HPLC quantification of microcystins}

Microcystins concentration was quantified by HPLC system following the methods described previously in Pham et al., (2015). Briefly, a reversephase HPLC system with UV-visible photodiode array (PDA) detector (Shimadzu 10A series, Kyoto, Japan) was equipped with a silica-based, reversephase $\mathrm{C}_{18}$ column (Waters SunFire ${ }^{\mathrm{TM}} 5 \mu \mathrm{m}, 3 \times 250$ $\mathrm{mm}$, Milford, Massachusetts, USA) and maintained at $40^{\circ} \mathrm{C}$. The MCs content in samples were separated with a mobile phase consisting of methanol: $0.05 \mathrm{M}$ phosphate buffer $(\mathrm{pH} 2.5 ; 50: 50 \mathrm{v} / \mathrm{v})$ at a flow rate of $0.58 \mathrm{~mL} / \mathrm{min}$. Microcystin congeners were detected by UV detection at $238 \mathrm{~nm}$ and identified on the basis of both their retention time and characteristic UV spectra. Microcystins purchased from Wako Pure Chemical Industries, Ltd. (Chuoku, Osaka, Japan), were used as standards.

\section{RESULTS}

\section{Isolation and morphological characteristics of cyanobacteria}

Microscopic examination of the cyanobacterial bloom samples revealed the dominance of Microcystis (mainly M. aeruginosa) and the less frequent occurrence of other genera (Dolichospermum, Arthrospira, Planktothrix, Pseudanabaena, and 
Cylindrospermopsis). Identification of individual Microcystis colonies revealed the occurrence of four species: M. aeruginosa, M. botrys, M. wesenbergii and M. panniformis (Fig. 1). A total of 15 Microcystis strains were isolated from the cyanobacterial and maintained them in cultures.

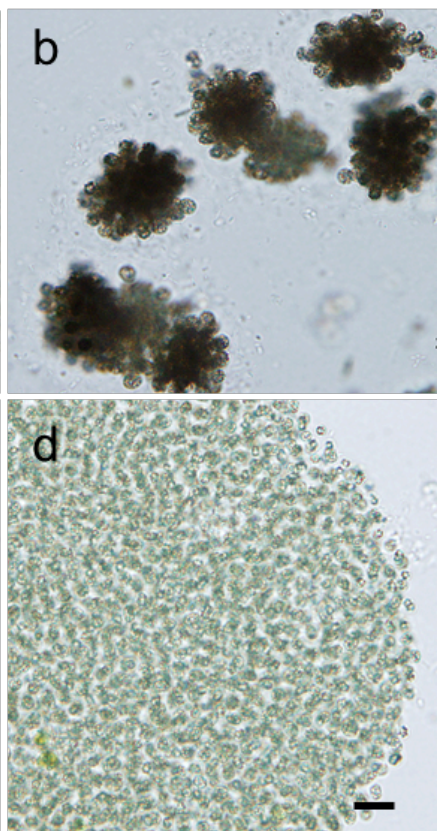

Figure 1. (a) M. aeruginosa, (b) M. botrys, (c) M. wesenbergii, (d) M. panniformis. Scale bar: $10 \mu \mathrm{m}$.

Molecular characterization of the Microcystis isolates

Isolated strains were examined by the $16 \mathrm{~S}$ rRNA and the $m c y D$ fragments. The $16 \mathrm{~S}$ rRNA fragments presented in all strains confirmed that all strains examined were cyanobacteria. The use of the mcyDF2/mcyD-R2 primers in the PCR yielded $300 \mathrm{bp}$ amplicons of the different studied strains, indicating the presence of $m c y D$ genes in these strains. In total, the $m c y D$ region was amplified for 10 of the 15 strains (Fig. 2). This amplicon was obtained from Microcystis isolates, which correspond to potential toxigenic strains, since they presented the mcy genes. The strains DT-bo10, DT-bo12, DT-bo13 corresponding to the cyanobacterium $M$. botrys and the strains DT-we14, DT-we15 corresponding to the cyanobacterium $M$. wesenbergii could not be amplified despite the fact that the procedure was repeated several times.
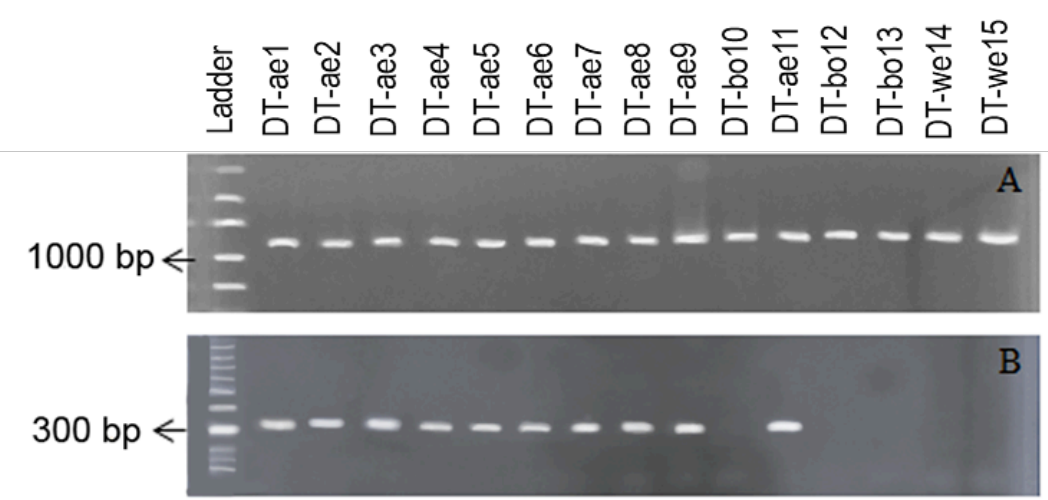

Figure 2. Ethidium bromide stained agarose electrophoresis gels showing PCR amplification products from selected strains. A: $16 \mathrm{~S}$ rRNA amplification products. B: mcyD amplification products. Ladder: PHY ladder; other lanes represent the different strains in the study (See list in Table 1). 


\section{Quantification of microcystins with HPLC}

Results of HPLC analysis indicated that 10/15 cultured strains contained MCs. All strains positive with the $m c y D$ produced MCs. MCs producing strains were classified into the $M$. aeruginosa (DTae1, DT-ae2, DT-ae3, DT-ae4, DT-ae5, DT-ae6, DTae7, DT-ae8, DT-ae9 and DT-ae11), while non MC producing strains were belonging to $M$. botrys and M. wesenbergii (DT-bo10, DT-bo12, DT-bo13, DTwe14 and DT-we15). The total concentration of MCs from toxic isolated strains ranged from 89.1 to 1,218 $\mu \mathrm{g} / \mathrm{g}$ DW (Table 1). The MCs content of these strains was quite variable. The minimum content of MCs was found in the strain DT-ae4 $(89.1 \mu \mathrm{g} / \mathrm{g} \mathrm{DW})$ and the maximum in DT-ae11 $(1,218 \mu \mathrm{g} / \mathrm{g} \mathrm{DW})$.

Table 1. List of isolated strains and bloom samples showing taxonomic assignment, amplification of the mcy $D$ region, total microcystin content, and LC50 values

\begin{tabular}{|c|c|c|c|c|c|}
\hline Source & Strain & Taxonomic assignment & mcyD & $\begin{array}{l}\text { MC } \\
(\mu \mathrm{g} / \mathrm{g} \mathrm{DW})\end{array}$ & $\begin{array}{l}\text { LC50 (mg DW } \\
\text { biomass/L) }\end{array}$ \\
\hline \multirow{17}{*}{$\begin{array}{l}\text { Dau Tieng } \\
\text { reservoir }\end{array}$} & DT-ae1 & M. aeruginosa & + & 113.5 & 214 \\
\hline & DT-ae2 & M. aeruginosa & + & 237.9 & 320 \\
\hline & DT-ae3 & M. aeruginosa & + & 146.8 & 275 \\
\hline & DT-ae4 & M. aeruginosa & + & 89.1 & 256 \\
\hline & DT-ae5 & M. aeruginosa & + & 548.4 & 189 \\
\hline & DT-ae6 & M. aeruginosa & + & 1013.4 & 196 \\
\hline & DT-ae7 & M. aeruginosa & + & 134.7 & 264 \\
\hline & DT-ae8 & M. aeruginosa & + & 297.8 & 198 \\
\hline & DT-ae9 & M. aeruginosa & + & 687.4 & 192 \\
\hline & DT-bo10 & M. botrys & - & - & 328 \\
\hline & DT-ae11 & M. aeruginosa & + & 1,218 & 255 \\
\hline & DT-bo12 & M. botrys & - & - & 272 \\
\hline & DT-bo13 & M. botrys & - & - & 411 \\
\hline & DT-we14 & M. wesenbergii & - & - & 380 \\
\hline & DT-we15 & M. wesenbergii & - & - & 365 \\
\hline & Bloom 1 & \multirow{2}{*}{\multicolumn{2}{|c|}{ Collected natural biomass }} & 568.3 & 169 \\
\hline & Bloom 2 & & & 465.8 & 183 \\
\hline
\end{tabular}

\section{Acute toxicity bioassays with D. magna}

No mortality was observed at $48 \mathrm{~h}$ in the control. On the other hand, exposure to some of the crude extracts induced mortality in D. magna neonates, which allowed for the calculation of the $48 \mathrm{~h}$ LC50 for those cases in which $50 \%$ mortality was within the interval of the tested concentrations. The means of the $48 \mathrm{~h}$ LC50 were shown in table 1. Strains DT-bo10, DT-bo12, DT-bo13 $(M$. botrys) and DT-we14, Dt-we15 (M. wesenbergii) and DT-ae2 ( $M$. aeruginosa) had the highest LC50 values (272 to $411 \mathrm{mg} / \mathrm{L}$ dry biomass) and DT-ae5, DT-ae6, DT-ae8, DT-ae9 were the most toxic strains to $D$. magna. As can be seen in Table 1, although MCs were not detected in all of the strains, all of the strains induced acute toxicity, the highest LC50 corresponding to the strain DT-bo11 (M. botrys) which did not produce MCs. In addition, comparison of the mortality results of collected natural biomass and isolated strains in Tables 1 revealed that the amount of biomass required to produce the lethal effect was, in general, lower when using collected material than when using the biomass from the culture of toxigenic strains isolated from the same sites. This indicated that the biomass of cyanobacteria from natural bloom caused more toxic effects than the cultured biomass did (Table 1).

\section{DISCUSSION}

In Vietnam, there are many artificial lakes used for water supplies and recreational activities in 
which cyanobacterial bloom formation associated with MCs production is frequently increased due to the high degree of eutrophication (Hummert et al., 2001; Duong 2014; Dao et al., 2016; Pham et al., 2017). MCs concentration exceed the WHO guideline value of $1.0 \mu \mathrm{g} / \mathrm{L}$ have also been reported in the Tri An and Dau Tieng reservoirs (Pham et al., 2015; Dao et al., 2016). This deserves special attention given the potential risk to human health and animal sanitation posed by blooms, since toxicity has been document to $75 \%$ of blooms cases (Chorus, Batram, 1999). Among the toxic species, $M$. aeruginosa is one of the most common and widespread bloom-forming cyanobacteria in freshwater environments. This species was also reported the bloom-forming in many Vietnamese water bodies (Hummert et al., 2001; Duong 2014; Dao et al., 2016; Pham et al., 2017). In this study we found that $M$. aeruginosa was the bloom-forming and the main toxin produces in the Dau Tieng reservoir. We strongly recommend further investigations to elucidate the cause and mitigate of these blooms.

PCR-based detection of genes involved in the synthesis of MCs is a reliable technique and has been successfully applied for determination of toxic and non-toxic cyanobacteria worldwide (Hisbergues et al., 2003; Bittencourt-Oliveira et al., 2010; Martins et al., 2011). Previous study have showed that the $m c y D$ which encodes for parts of both the $\beta$-ketoacyl synthase and the acyltransferase domains (Rantala et al., 2004; Pham et al., 2015) is one of the best molecular markers for determination of potential toxicity of cyanobacteria. In this study, the amplification of the $m c y D$ showed again reliable results in the distinguish toxic and non-toxic Microcystis. Therefore, we recommend using this fragment for the determination of toxic genetic of Microcystis in other Vietnamese waters.

The acute toxicity bioassays with CCE of bloom biomass and cultured Microcystis can affect cladocerans adversely, obtaining similar results to those found by Arzate-Cárdenas (2010). The LC50 calculated for the assays performed with bloom biomass from the sampling sites was lower in all cases than that of the isolated Microcystis strains from the same sites. Probably due to the fact that the biomass of the blooms is constituted by a mixture of MCs and other cyanotoxins such as anatoxins, cylindropermopsin, so that could contribute to the toxic effect on Daphnia.
It was found that both toxic and non-toxic strains caused death of D. magna neonates. These results were well in agreement to findings by other researcher (FerrÃo-Filho et al., 2000; Dao et al., 2013). And Microcystis strains with different MCs contents resulted in different LD50 on D. magna neonates. This could be explained by the fact that different strains produced different chemical structure of MCs, since the structure affects its toxic properties (Prieto et al., 2006). Microcystis strains are able to produce more than one MC variant (Mowe et al., 2014; Pham et al., 2015), which could be related to the genetic structure of the mcy genes cluster (Mikalsen et al., 2003). In addition, Dao et al., (2013) found that not all crude extracts exert the same effects on tested organisms and not all organisms react in the same way with the harmful substances. Burýšková et al., (2006) points out that MCs are not the only or major toxic compound in the complex cyanobacterial samples and it is necessary to study in more detail the possible interactions of other toxic compound in the cyanobacterial biomass. This issue must be further investigated.

\section{CONCLUSIONS}

Bloom of cyanobacteria and Microcystis strains with a large toxigenic potential were found in the Dau Tieng reservoir, which could pose risk on the aquatic communities and human health. The results revealed that toxic effects on D. magna were not only related with the MCs concentration, but other substances and metabolites present in the crude extracts also exerted acute toxic effect. The analytical methods in this study (PCR and HPLC) were useful and reliable for determining $\mathrm{MC}$ production and its potential contribution to the acute toxic effects.

Acknowledgements: This research was founded by Vietnam National Foundation for Science and Technology Development (NAFOSTED) under grant number "106-NN.04-2015.72".

\section{REFERENCES}

Arzate-Cárdenas MA, Olvera-Ramírez R, MartínezJerónimo F (2010) Microcystis toxigenic strains in urban lakes: a case of study in Mexico City. Ecotoxicology 19: 1157-1165.

Ballot A, Krienitz L, Kotut K, Wiegand C, Metcalf JS, Codd GA, Pflugmacher S (2004) Cyanobacteria and 
cyanobacterial toxins in three alkaline Rift Valley lakes of Kenya Lakes Bogoria, Nakuru and Elmenteita. J Plankton Res 26: 925-935.

Belcher H, Swale E (1988) Culturing algae-A guide for schools and colleges, The Ferry House, UK.

Bittencourt-Oliveira MC, Santos DM, Moura NA (2010) Toxic cyanobacteria in reservoirs in northeastern Brazil: detection using a molecular method. Braz J Biol 70: 10051010 .

Burýšková B, Hilscherová K, Babica P, Vršková D, Maršálek B, Bláha L (2006) Toxicity of complex cyanobacterial samples and their fractions in Xenopus laevis embryos and the role of microcystins. Aquat Toxicol 80: 346-354.

Chorus I, Bartram J (1999) Toxic Cyanobacteria in Water: A guide to their public health consequences, monitoring and management, Published on behalf of WHO, Spon Press, London.

Dao T-S, Ortiz-Rodríguez R, Do-Hong L-C, Wiegand C (2013) Non-microcystin and non-cylindrospermopsin producing cyanobacteria affect the biochemical responses and behavior of Daphnia magna. Int Rev Hydrobiol 98: 235-244.

Dao T-S, Nimptsch J, Wiegand C (2016) Dynamics of cyanobacteria and cyanobacterial toxins and their correlation with environmental parameters in Tri An reservoir, Vietnam. J Water Health 14: 699-712.

Dittmann E, Wiegand C (2006) Cyanobacterial toxinsoccurrence, biosynthesis and impact on human affairs. Mol Nutr Food Res 50: 7-17.

Duong T, Jähnichen S, Le T, Ho C, Hoang T, Nguyen T, Vu T, Dang D (2014) The occurrence of cyanobacteria and microcystins in the Hoan Kiem Lake and the Nui Coc reservoir (North Vietnam). Environ Earth Sci 71: 24192427

FerrÃo-Filho AS, Azevedo SMFO, DeMott WR (2000) Effects of toxic and non-toxic cyanobacteria on the life history of tropical and temperate cladocerans. Freshwater Biol 45: 1-19.

Hisbergues M, Chriastiansen G, Rouhiainen L, Sivonen K, Borner T (2003) PCR-based identification of microcystinproducing genotypes of different cyanobacterial genera. Arch Microbiol 180: 402-410.

Hummert C, Dahlmann J, Reinhardt K, Dang H, Dang D, Luckas B (2001) Liquid chromatography-mass spectrometry identification of microcystins in Microcystis aeruginosa strain from lake Thanh Cong, Hanoi, Vietnam. Chromatographia 54: 569-575.

Janse I, Kardinaal WE, Meima M, Fastner J, Visser PM, Zwart G (2004) Toxic and nontoxic microcystis colonies in natural populations can be differentiated on the basis of
rRNA gene internal transcribed spacer diversity. Appl Environ Microbiol 70: 3979-3987.

Kaebernick M, Neilan BA, Borner, T, Dittmann E (2000) Light and the transcriptional response of the microcystin biosynthesis gene cluster. Appl Environ Microbiol 66: 3387-3392.

Komárek J, Anagnostidis K (1989) Modern approach to the classification system of Cyanophytes. 4 - Nostocales. Arch Hydrobiol Suppl 82: 247-345.

Komárek J, Anagnostidis K (1999) Cyanoprokaryota 1. Teil: Chroococcales. 548 pp.

Komárek J, Anagnostidis K (2005) Cyanoprokaryota 1. Teil: Oscillatoriales. (19/2), 1-759.

Kilham SS, Kreeger DA, Lynn SG, Goulden CE, Herrera L (1998) COMBO: a defined freshwater culture medium for algae and zooplankton. Hydrobiologia 377: 147-159.

Kotai J (1972) Instructions for preparation of modified nutrient solution Z8 for algae. Norwegian Institute for Water research Oslo B-11/69, 1-5.

Martins A, Moreira C, Vale M, Freitas M, Regueiras A, Antunes A, Vasconcelos V (2011) Seasonal dynamics of Microcystis spp. and their toxigenicity as assessed by qPCR in a temperate reservoir. Mar Drugs 9: 1715-1730.

Mikalsen B, Boison G, Skulberg OM, Fastner J, Davies W, Gabrielsen TM, Rudi K, Jakobsen KS (2003) Natural variation in the microcystin synthetase operon mcyABC and impact on microcystin production in Microcystis strains. J Bacteriol 185: 2774-2785.

Mowe MAD, Mitrovic SM, Lim RP, Furey A, Yeo DCJ (2014) Tropical cyanobacterial blooms: a review of prevalence, problem taxa, toxins and influencing environmental factors. J Limnol 74: 205-224.

Nishizawa T, Asayama M, Fujii K, Harada K, Shirai M (1999) Genetic analysis of the peptide synthetase genes for a cyclic heptapeptide microcystin in Microcystis spp. $J$ Biochem 126: 520-529.

OECD (2004). Daphnia sp. Acute immobilization test, OECD guideline for testing of chemicals No. 202. Organization for the Economical Cooperation and Development.

Pedro O, Correia D, Lie E, Skåre JU, Leão J, Neves L, Sandvik M, Berdal KG (2011) Polymerase chain reaction (PCR) detection of the predominant microcystin-producing genotype of cyanobacteria in Mozambican lakes. Afr J Bio 10: $19299-19308$

Pham TL, Dao TS, Shimizu K, Lan-Chi DH, Utsumi M (2015) Isolation and characterization of microcystinproducing cyanobacteria from Dau Tieng reservoir, Vietnam. Nova Hedwigia 101: 3-20. 
Pham TL, Dao TS, Tran ND, Nimptsch J, Wiegand C, Motoo U (2017) Influence of environmental factors on cyanobacterial biomass and microcystin concentration in the Dau Tieng reservoir, a tropical eutrophic water body in Vietnam. Ann Limnol - Int J Lim 53: 89-100.

Pietsch C, Wiegand C, Amé MV, Nicklisch A, Wunderlin D, Pflugmacher S (2001) The effects of a cyanobacterial crude extract on different aquatic organisms: Evidence for cyanobacterial toxin modulating factors. Environ Toxicol 16: $535-542$.

Prieto AI, Jos A, Pichardo S, Moreno I, Camean AM (2006) Differential oxidative stress responses to microcystins LR and RR in intraperitoneally exposed tilapia fish (Oreochromis sp.). Aquat Toxicol 77: 314-321.

Rantala A, Fewer DP, Hisbergues M, Rouhiainen L, Vaitomaa J, Borner T, Sivonen K (2004) Phylogenetic evidence for the early evolution of microcystin synthesis. Proc Natl Acad Sci USA 101: 568-573.

Rantala A, Rajaniemi-Wacklin P, Lyra C, Lepisto L, Rintala J, Mankiewicz-Boczek J, Sivonen K (2006) Detection of microcystin-producing cyanobacteria in Finnish lakes with genus-specific microcystin synthetase gene E $(m c y E)$ PCR and associations with environmental factors. Appl Environ Microbiol 72: 6101-6110.
Rouhiainen L, Vakkilainen T, Siemer BL, Buikema W, Haselkorn R, Sivonen K (2004) Genes coding for hepatotoxic heptapeptides (microcystins) in the cyanobacterium Anabaena strain 90. Appl Environ Microbiol 70: 686-692.

Sarma SS, Nandini S (2006) Review of recent ecotoxicological studies on cladocerans. J Environ Sci Health B 41: 1417-1430.

Stephan CE (1977) Methods for calculating an LC50. In: Mayer FI, Hamelink JL (eds) Aquatic toxicology and hazard evaluation. ASTM STP 634, American Society for Testing and Materials, Philadelphia, pp 65-84.

Tillett D, Dittmann E, Erhard M, von Dohren H, Borner T, Neilan BA (2000) Structural organization of microcystin biosynthesis in Microcystis aeruginosa PCC7806: an integrated peptide-polyketide synthetase system. Chem Biol 7: 753-764.

U.S. Environmental Protection Agency (2002) Methods for measur-ing the acute toxicity of effluents and receiving waters to freshwater and marine organisms. 5th Ed. EPA821-R-02-012.

Urbach E, Robertson DL, Chisholm SW (1992) Multiple evolutionary origins of prochlorophytes within the cyanobacterial radiation. Nature 355: 267-270.

\title{
PHÂN TÍCH KHẢ NĂNG SINH ĐộC TỐ CỦA MộT SỐ CHỦNG VI KHUẪN LAM MICROCYSTIS Ở HỒ DẦU TIẾNG
}

\author{
Phạm Thanh Lưu ${ }^{1,2}$, Ngô Xuân-Quảng ${ }^{1,2}$ \\ ${ }^{1}$ Viện Sinh hoc nhiệt đới, Viện Hàn lâm Khoa hoc và Công nghệ Việt Nam \\ ${ }^{2}$ Học viện Khoa học và Công nghệ, Viện Hàn lâm Khoa học và Công nghệ Việt Nam
}

\section{TÓM TẮT}

Vi khuẩn lam Microcystis thường gây nở hoa ở hồ Dầu Tiếng dùng cho cấp nước sinh hoạt. Trong nghiên cứu này, phương pháp sinh học phân tử và phương pháp thử nghiệm cấp tính với vi giáp xác Daphnia magna được sử dụng để phân tích khả năng sinh độc tố và xác định tính độc của các chủng Microcystis. Đoạn gen $16 \mathrm{~S}$ rRNA được sử dụng để nhận dạng vi khuẩn lam và phương pháp kiểm tra đoạn gen $m c y D$ được sử dụng để kiểm tra khả năng sinh độc tố của các chủng Microcystis. Hàm lượng độc tố microcystins (MCs) được phân tích bằng phương pháp sắc ký lỏng hiệu năng cao (HPLC). Kết quả cho thấy có $9 / 15$ chủng Microcystis dương tính với đoạn gen $m c y D$ từ đó giúp kết luận các chủng này là các chủng có khả năng sinh độc. Độc tố $\mathrm{MCs}$ (MC-RR, MC-LR và MC-YR) được tìm thấy trong sinh khối của tất cả các chủng sinh độc với hàm lượng cao nhất là $1218 \mu \mathrm{g} / \mathrm{g}$ trọng lượng khô $(\mathrm{DW})$. Thí nghiệm cấp tính với Daphnia cho thấy các chủng sinh độc và không sinh độc đều gây chết động vật thí nghiệm với liều gây chết $50 \%$ (LD50) dao động từ 189 đến $411 \mathrm{mg}$ DW/L. Tính độc lên Daphnia ở các chủng phân lập được không phụ thuộc vào hàm lượng độc tố do chúng sinh ra. Điều này cho thấy có sự hiện diện của các hợp chất gây độc khác ngoài MCs trong sinh khối của các chủng Microcystis. Kết quả của nghiên cứu cho thấy vi khuẩn lam ở hồ Dầu Tiếng gây ảnh hưởng xấu đến quần xã thủy sinh vật và sức khỏe con người.

Từ khóa: Sinh độc tố microcystin, Microcystis, mcy gen, phuơng pháp PCR, Hồ Dầu Tiếng 